\title{
Frost Dehardening and Rehardening of Hydrangea macrophylla Stems and Buds
}

\author{
Majken Pagter ${ }^{1}$ and Michelle Williams \\ Department of Food Science, Aarhus University, Kirstinebjergvej 10, \\ DK-5792 Aarslev, Denmark
}

Additional index words. freezing tolerance, deacclimation, reacclimation, electrolyte leakage, warm spells

\begin{abstract}
Hydrangea macrophylla is a popular and commercially important flowering shrub, but frost injury of buds and current-year shoots is a common problem in some of its cultivars. As a result of climate warming, temperate winters are becoming progressively milder, and temperature patterns are becoming increasingly irregular with an increased frequency of warm spells. Warm spells may induce premature dehardening, increasing the risk of subsequent freezing injuries. This study investigated cold-hardiness of stems and buds of Hydrangea macrophylla ssp. macrophylla (Thunb.) Ser. 'Alma' during dehardening in response to simulated warm spells and subsequent rehardening in January and early March. Plants were acclimated in the field and dehardened in the greenhouse at controlled warm temperatures for various durations. Dehardened plants were rehardened for up to 12 days in an unheated greenhouse (January) or in the field (March). Buds of $\boldsymbol{H}$. macrophylla were slightly less cold-hardy than stems. In both stems and buds, the dehardening resistance and the rate of dehardening were influenced by temperature, but buds appeared to be less resistant to dehardening and dehardened faster than stems. In stems, dehardening proceeded faster in March than in January, and the capacity of the stems to reharden seemed reduced, indicating that both dehardening and rehardening were influenced by the progression of winter. Results of this study indicate that buds of $\boldsymbol{H}$. macrophylla are more sensitive to frost injury than stems and the vulnerability of stems to frost injuries, caused by an unstable temperature regime, changes during the winter season.
\end{abstract}

Hydrangea macrophylla is a popular flowering shrub, widely used and commercially important in landscape horticulture (Adkins et al., 2003). H. macrophylla is native to Japan (McClintock, 1957) and thrives in maritime regions but grows and flowers in most temperate regions where it is not damaged by cold temperatures. However, even in Denmark, which has a rather mild climate with a daily mean temperature of $0.9^{\circ} \mathrm{C}$ in December, January, and February (The Danish Meteorological Institute), frost injury or winter kill of buds and current-year shoots is a common problem. The consequences of bud freezing injuries in terms of quality and ornamental value are of horticultural importance. Flower buds of most H. macrophylla varieties are formed during the fall and overwinter on dormant stems. Flowering will therefore only occur the next year if terminal

Received for publication 25 Feb. 2011. Accepted for publication 23 June 2011.

This study was funded by the Danish Research Council for Technology and Production Sciences (Grant No. 274-08-0331), the Danish Council for Independent Research, through a young researchers award to MPA, and $\mathrm{The} \mathrm{Ib}$ Henriksen Foundation.

We thank Lillie Andersen and Christian R. Jensen for helpful comments on the manuscript.

${ }^{1}$ To whom reprint requests should be addressed; e-mail majken.pagter@agrsci.dk. and/or lateral flower buds are present and undamaged. Previous studies have shown that maximum stem cold-hardiness of different H. macrophylla cultivars varies between -17 and $-24{ }^{\circ} \mathrm{C}$ (Adkins et al., 2003; Pagter et al., 2008), but buds seem to be more susceptible to freeze injuries than stems (Pagter et al., 2008). Despite the key role of flower buds in $H$. macrophyllas ornamental and commercial value, cold-hardiness of $H$. macrophylla buds have, to our knowledge, never been quantified.

Insufficient midwinter-hardiness may account for some of the frost injuries encountered in H. macrophylla, but it is possible that late hardening in fall and/or premature dehardening in spring also limits the successful cultivation and flowering of $H$. macrophylla (Adkins et al., 2003). The risk of premature dehardening may be increasing as a result of global climate changes. Although temperate winters are becoming progressively milder, the temperature patterns have become increasingly irregular with an increased frequency of warm spells, during which plants tend to lose cold-hardiness, thereby increasing the risk of subsequent freezing injury $(\mathrm{Gu}$ et al., 2008). In addition, shifting phenological patterns such as an earlier start to the growing season and earlier flowering (Fitter and Fitter, 2002; Karlsen et al., 2007), consistent with climate warming, may enhance the risk of frost injuries caused by increasing temperature variation. To reduce the risk of frost injuries, $H$. macrophylla should ideally deharden slowly or late in response to unseasonable transient increases in temperature. In a previous study (Pagter et al., 2011), the timing and rate of dehardening of stems of H. macrophylla and the considerably more cold-hardy Hydrangea paniculata Sieb. were estimated in response to a simulated warm spell at constant $22 / 17{ }^{\circ} \mathrm{C}$ day/night. Data demonstrated that dehardening of stems of $H$. macrophylla followed a sigmoid curve with a short lag phase (less than $3 \mathrm{~d}$ ) followed by a fast dehardening rate. It was also observed that budbreak in $H$. macrophylla started after $5 \mathrm{~d}$ of dehardening, when stems were still hardy to $-10.9^{\circ} \mathrm{C}$. Because opening buds are generally expected to have lost most of their acclimated cold-hardiness (Kalberer et al., 2006), this supports the suggestion that buds of H. macrophylla are less cold-hardy than stems and/or that buds dehardened faster than stems, at least under constant warm temperatures.

In addition to the stability of the hardiness and the rate of dehardening, the effect of an unstable temperature regime on the frequency and severity of frost injuries also depends on the ability of the plants to reharden in response to low temperatures after a period of dehardening (Kalberer et al., 2006). Rehardening may be an important winter survival strategy in plants that deharden quickly on exposure to increased temperatures. Seasonal fluctuations in cold-hardiness (decreases followed by increases and vice versa), which indicate some capacity to reharden, have been documented in many plants (Cox and Stushnoff, 2001; Neuner et al., 1999; Sauter et al., 1996), and rehardening in controlled conditions after considerable losses of cold-hardiness has also been documented in some species (Eagles and Williams, 1992; Kalberer et al., 2007a, 2007b; Suojala and Lindén, 1997). However, in H. macrophylla, the potential rehardening capacity is largely unknown.

This study was conducted to 1) determine the hardiness of buds of H. macrophylla and to determine if buds are less cold-hardy than stems; 2) investigate dehardening resistance and loss of cold-hardiness of stems and buds of non-dormant $H$. macrophylla under different temperature conditions; and 3 ) determine if stems and buds of non-dormant $H$. macrophylla have an ability to reharden after a period of dehardening.

\section{Materials and Methods}

Plant material. Evaluations were carried out using 2-year-old vegetatively propagated and commercially produced Hydrangea macrophylla ssp. macrophylla (Thunb.) Ser. 'Alma' grown in 3.5-L pots containing sphagnum peat. Two hundred plants were purchased from Gunnar Christensen's Nursery, Denmark (lat. $55^{\circ} 26^{\prime} \mathrm{N}$ ) in the beginning of Oct. 2009, at which time the plants had been maintained outside since the spring of 2009. When delivered to the Department of Food Science, Aarhus University in Aarslev, Denmark (lat. $55^{\circ} 18^{\prime} \mathrm{N}$ ) plants were maintained outside in pots buried in the soil to 
avoid root frost injuries and to facilitate plant removal and moving when needed. Hence, the plants underwent cold-hardening under natural conditions. Local air temperature data were obtained from the department's climate station, which is operated by the Danish Meteorological Institute. October and November of 2009 turned out to be mild without freezing temperatures (Fig. 1). In December, the average daily mean air temperature dropped to $1{ }^{\circ} \mathrm{C}$ and reached an absolute minimum of $-14.4{ }^{\circ} \mathrm{C}$ mid-December. Average daily mean temperatures in January and February of 2010 were -3.0 and $-1.6{ }^{\circ} \mathrm{C}$, respectively, and in January and most of February, subzero temperatures occurred daily. Before initiating the experiment, we did not determine if the plants had emerged from endodormancy. However, previous observations have shown that H. macrophylla 'Alma' was released from endodormancy before January (Pagter et al., 2011); therefore, we expected that the plants in this evaluation were non-endodormant.

Dehardening and rehardening treatments. In early January, five fully cold-hardened plants were selected to estimate midwinter cold-hardiness ( $0 \mathrm{~d}$ of dehardening). Another 90 plants were selected and randomly divided into three groups and moved into three greenhouse compartments for dehardening. The dehardening treatments consisted of a 7.5-h photoperiod (corresponding to natural daylength) at 150 to $200 \mu \mathrm{mol} \cdot \mathrm{m}^{-2} \cdot \mathrm{s}^{-1} \mathrm{com}$ bined with day/night temperatures of 20 / $15{ }^{\circ} \mathrm{C}, 15 / 10{ }^{\circ} \mathrm{C}$, or $10 / 5{ }^{\circ} \mathrm{C}$. Cold-hardiness estimations of current-year stems and buds were carried out after 4,8 , and $12 \mathrm{~d}$ of dehardening (DOD). At each sampling time, buds and stems were randomly collected from five plants per treatment.

To evaluate the rehardening capacity of buds and stems, i.e., the increase in coldhardiness of dehardened buds and stems after cold treatment, the deacclimating plants that had not been harvested during dehardening were moved to a heated greenhouse for rehardening. However, after $1 \mathrm{~d}$ in the heated greenhouse, the plants were transferred to an unheated greenhouse, because the temperature in the heated greenhouse fluctuated between 5 to $7{ }^{\circ} \mathrm{C}$, which may be too high to effectively induce rehardening. Inside the unheated greenhouse the air temperature was on average 2 to $3{ }^{\circ} \mathrm{C}$ higher than in the field. Maximum and minimum air temperatures during rehardening were close to 10 and $-10{ }^{\circ} \mathrm{C}$, respectively, but most of the time the temperature fluctuated between 5 and $-5{ }^{\circ} \mathrm{C}$ (Fig. 2A). Cold-hardiness of stems and buds were evaluated after 4, 8 and $12 \mathrm{~d}$ of rehardening (DOR) using five replicates per treatment.

At the beginning of March, the experiment was repeated, but this time, the dehardening temperatures were adjusted to $16 /$ $11{ }^{\circ} \mathrm{C}, 13 / 8{ }^{\circ} \mathrm{C}$, and $10 / 5{ }^{\circ} \mathrm{C}$ day/night. The photoperiod was supposed to be $11 \mathrm{~h}$ at 150 to $200 \mu \mathrm{mol} \cdot \mathrm{m}^{-2} \cdot \mathrm{s}^{-1}$, but as a result of a mistake, the daylength was $24 \mathrm{~h}$. However, presumably plants were unable to detect the extended photoperiod because they were lacking leaves

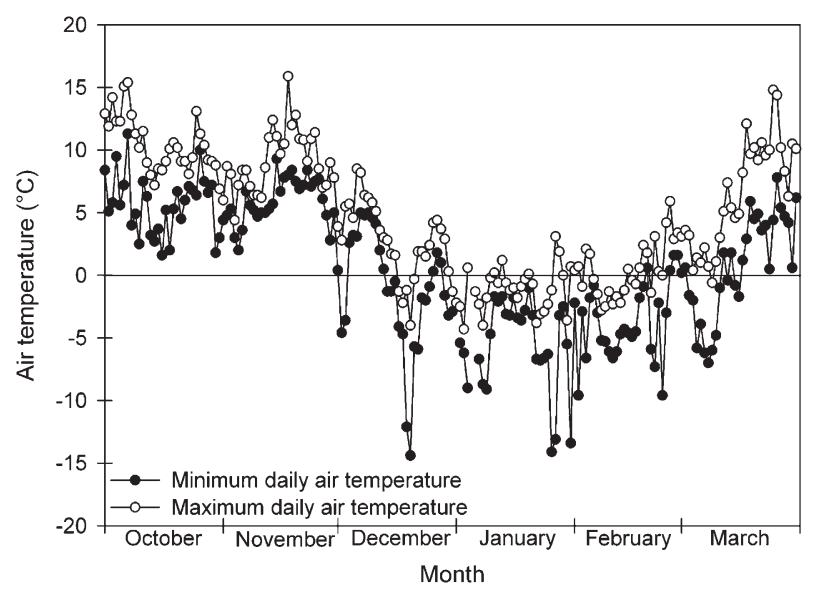

Fig. 1. Minimum and maximum daily air temperatures $\left({ }^{\circ} \mathrm{C}\right)$ at the experimental site from Oct. 2009 to Apr. 2010.


Fig. 2. Hourly air temperatures $\left({ }^{\circ} \mathrm{C}\right)$ during $12 \mathrm{~d}$ of cold rehardening of Hydrangea macrophylla in an unheated greenhouse in January (A) and in the field in March (B).

and hence the phytochrome-mediated response to photoperiod (Fosket, 1994). The unwanted extended photoperiod would therefore not have influenced dehardening. In midMarch the air temperature was considerably higher than in January and after dehardening, the remaining plants were moved outside, rather than to an unheated greenhouse, for rehardening. During the first 4 DOR, the air temperature was on average $2.3{ }^{\circ} \mathrm{C}$, and during the last $8 \mathrm{DOR}$, the air temperature increased to on average $6.8{ }^{\circ} \mathrm{C}$ (Fig. 2B). In the second experiment, only cold-hardiness of stems was evaluated, because most of the terminal and lateral buds of the plants used in the second experiment had been freeze-injured in January or February, when the plants were held outside.

Cold-hardiness evaluations. Freezing tolerance of stems and buds was determined at 
seven temperatures: one control $\left(4^{\circ} \mathrm{C}\right)$ and six subfreezing temperatures. Temperatures chosen depended on the projected hardiness of stems and buds after a given dehardening and rehardening treatment. Freeze tolerance of stems was determined using the electrolyte leakage method (Pagter et al., 2011). One 3 -cm-long piece of internodal stem tissue was rinsed under cold running tap water for $15 \mathrm{~s}$ and then under cold running demineralized water for $15 \mathrm{~s}$. After rinsing, the samples were placed in $70-\mathrm{mL}$ test tubes containing $200 \mu \mathrm{L}$ of demineralized water (to initiate ice formation), and samples were placed in a prechilled temperature-controlled freezer for the freezing treatment. The samples were cooled at a rate of maximum $5{ }^{\circ} \mathrm{C}$ per hour to $0{ }^{\circ} \mathrm{C}$ and subsequently at $2{ }^{\circ} \mathrm{C}$ per hour until the selected temperature was reached. The selected temperature was maintained for $2 \mathrm{~h}$; thereafter, the samples were withdrawn and thawed overnight on ice at $4{ }^{\circ} \mathrm{C}$. Ions were extracted with $35 \mathrm{~mL}$ demineralized water for $24 \mathrm{~h}$ at room temperature and the electrical conductivity was measured ( $\left.\mathrm{EC}_{\text {frozen }}\right)$ using a CDM80 Conductivity Meter equipped with a CDC114 electrode (Radiometer, Copenhagen, Denmark) or an ION570 ISE meter with temperature-corrected display (Radiometer, Copenhagen, Denmark). After determination of the EC, samples were autoclaved for $1 \mathrm{~h}$ to allow maximum leakage of ions. After autoclaving, the samples were allowed to cool to room temperature and the $\mathrm{EC}$ was measured again $\left(\mathrm{EC}_{\text {autoclave }}\right)$. The $\mathrm{EC}$ of demineralized water $\left(\mathrm{EC}_{\mathrm{water}}\right)$ was measured to determine the zero level of EC. Relative electrolyte leakage (REL) was calculated as $\mathrm{REL}=\left(\mathrm{EC}_{\text {frozen }}-\mathrm{EC}_{\text {water }}\right) \times$ $100 /\left(\mathrm{EC}_{\text {autoclave }}-\mathrm{EC}_{\text {water }}\right)$ (Burr et al., 2001).
To determine bud freezing tolerance, terminal buds with attached stems were pruned to equal lengths (2 to $3 \mathrm{~cm}$ ) under water, wrapped in moist paper towels to ensure ice nucleation, and inserted into small sealed plastic bags. Bud samples were incubated together with the stem samples in a pre-chilled controlled freezer on top of an aluminum grating and were subjected to the same freezing profile as stem samples. After freezing and thawing, overnight on ice at $4{ }^{\circ} \mathrm{C}$, buds with attached stem pieces were incubated at $20{ }^{\circ} \mathrm{C}$ for 1 to $3 \mathrm{~d}$ before examining bud damage. Buds were then dissected under a dissecting microscope and assessed for injury. Buds were classified as dead (all brown), alive (green and succulent), or injured (some parts brown and other parts green). In most cases, injured referred to browning of the flower primordia, but in some cases, it referred to browning of the base of the bud.

Data analysis. Stem freezing tolerance was estimated as $\mathrm{LT}_{50}$ values, the temperature representing $50 \%$ REL. At each time, data for all five replicates were fitted by regression analysis (PROC NLIN of SAS; SAS Institute, Cary, NC) to the sigmoid function $\mathrm{REL}=\mathrm{REL}_{\min }+\left(\mathrm{REL}_{\max }-\right.$ $\left.\mathrm{REL}_{\text {min }}\right) /\left\{1+\exp \left[\mathrm{c}^{*}(\mathrm{~d}-\mathrm{T})\right]\right\}$, where $\mathrm{REL}_{\text {min }}$ is the base line of REL, REL $\mathrm{RLx}_{\text {max }}$ is the maximum REL, $\mathrm{c}$ is the slope of the function at the inflection point $\mathrm{d}$, and $\mathrm{T}$ is the treatment temperature. The temperature (d) at the inflection point was used as $\mathrm{LT}_{50}$ (Väinolä and Repo, 1999). Differences between $\mathrm{LT}_{50}$ estimates were taken as significant when the SES did not overlap.

The ordinal categories describing bud freezing tolerance were analyzed using a proportional

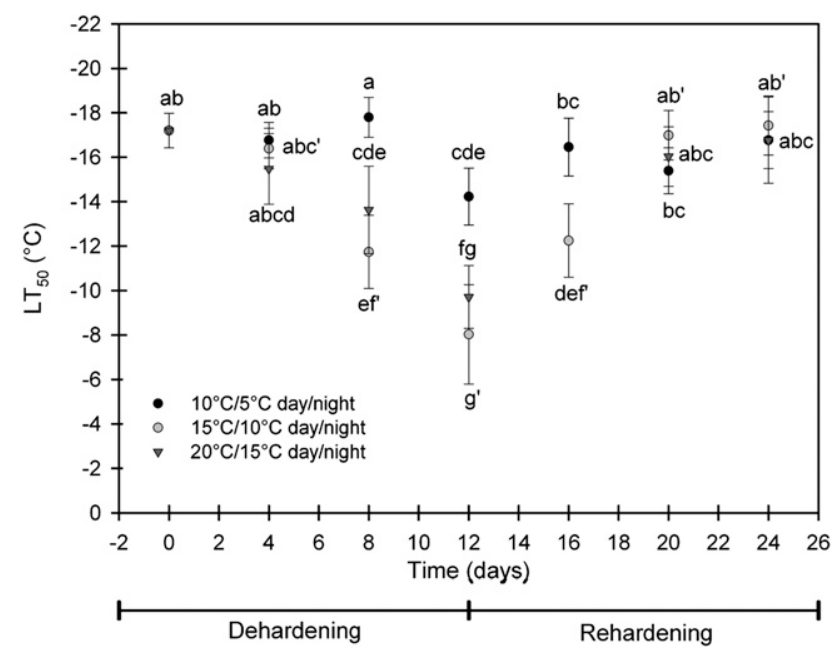

Fig. 3. Cold-hardiness estimated as temperatures representing 50\% relative electrolyte leakage $\left(\mathrm{LT}_{50}\right)$ of stems of Hydrangea macrophylla subjected to $12 \mathrm{~d}$ of dehardening followed by $12 \mathrm{~d}$ of rehardening in January. During dehardening, plants were subjected to the indicated different day and night temperatures. $\mathrm{LT}_{50}$ values $\left[\right.$ mean $\left.\pm \mathrm{SE}\left({ }^{\circ} \mathrm{C}\right)\right]$ are shown for five plants tested at seven temperatures Different letters indicate significant differences between $\mathrm{LT}_{50}$ values $(P<0.05)$. After $4 \mathrm{~d}$ of rehardening, $\mathrm{LT}_{50}$ values of plants dehardened at $20 / 15^{\circ} \mathrm{C}$ day/night could not be accurately estimated because the relative electrolyte leakage data were variable between replicates at specific freezing temperatures. Differences in $\mathrm{LT}_{50}$ values of plants dehardened at $15 / 10{ }^{\circ} \mathrm{C}$ day/night are indicated by marked letters for clarity.

Table 1. The probabilities of buds being alive, injured, or dead after exposure to $4^{\circ} \mathrm{C}$ or freezing to $-5,-10,-13$, or $-16^{\circ} \mathrm{C}$ as predicted by the proportional odds model. ${ }^{\mathrm{z}}$

\begin{tabular}{llccccc}
\hline \multirow{2}{*}{ Treatment } & & \multicolumn{5}{c}{ Test temp $\left({ }^{\circ} \mathrm{C}\right)$} \\
\cline { 3 - 7 } 0 DOD & Alive & 0.98 & -5 & -10 & -13 & -16 \\
& Injured & 0.02 & 0.06 & 0.34 & 0.44 & 0.46 \\
& Dead & 0.00 & 0.01 & 0.05 & 0.09 & 0.10 \\
& & & & & & \\
4 DOD & Alive & 0.96 & 0.97 & 0.80 & 0.68 & 0.66 \\
& Injured & 0.04 & 0.03 & 0.18 & 0.28 & 0.30 \\
& Dead & 0.00 & 0.00 & 0.02 & 0.04 & 0.04 \\
& & & & & & \\
8 DOD & Alive & 0.87 & 0.90 & 0.53 & 0.38 & 0.36 \\
& Injured & 0.12 & 0.09 & 0.40 & 0.50 & 0.50 \\
& Dead & 0.01 & 0.01 & 0.07 & 0.12 & 0.14 \\
& & & & & & \\
12 DOD & Alive & 0.65 & 0.72 & 0.24 & 0.15 & 0.13 \\
& Injured & 0.30 & 0.25 & 0.54 & 0.51 & 0.51 \\
& Dead & 0.05 & 0.03 & 0.22 & 0.44 & 0.36 \\
& & & & & & \\
4 DOR & Alive & 0.77 & 0.82 & 0.36 & 0.24 & 0.22 \\
& Injured & 0.20 & 0.16 & 0.50 & 0.54 & 0.54 \\
& Dead & 0.03 & 0.02 & 0.14 & 0.22 & 0.24 \\
\hline
\end{tabular}

${ }^{\text {zBuds were evaluated after } 0,4,8 \text {, or } 12 \mathrm{~d} \text { of }}$ dehardening (DOD) at $10 / 5{ }^{\circ} \mathrm{C}$ day/night followed by $12 \mathrm{~d}$ of rehardening (DOR). Most buds were injured or killed after 6 DOR as a result of a significant drop in air temperatures. Therefore, bud freezing tolerance could not be determined at 8 and 12 DOR, and only data from 4 DOR were included in the proportional odds model.

odds model (PROC LOGISTIC) with three response levels (alive, injured, or dead) and with dehardening treatment, treatment duration (time), and freeze test temperature as explanatory variables (McCullagh, 1980). The proportional odds model is a logistic model, which estimates the cumulative probabilities of buds being alive and buds being alive or injured depending on treatment, treatment duration, and freeze test temperature. Because a logit-based model cannot estimate 0 or 1 probabilities, $-16^{\circ} \mathrm{C}$ was the lowest temperature included in the proportional odds model. At lower temperatures, all buds in at least one treatment (typically $20 / 15^{\circ} \mathrm{C}$ day/night) appeared dead.

\section{Results}

In January, stem hardiness of H. macrophylla in the coolest environment remained unchanged during the first 8 DOD. However, after 12 DOD, hardiness had decreased significantly by $3{ }^{\circ} \mathrm{C}$ (Fig. 3). Dehardening progressed faster at temperatures of $15 / 10{ }^{\circ} \mathrm{C}$ or $20 / 15{ }^{\circ} \mathrm{C}$ compared with $10 / 5{ }^{\circ} \mathrm{C}$, whereas there were no significant differences in stem cold-hardiness between plants subjected to $15 / 10^{\circ} \mathrm{C}$ or $20 / 15^{\circ} \mathrm{C}$. Although stem hardiness of plants in the two warmest dehardening treatments was reduced $\approx 9{ }^{\circ} \mathrm{C}$ at $12 \mathrm{DOD}$, all plants rehardened. After 4 DOR, an increase in stem hardiness was observed in plants subjected to dehardening at $15 / 10{ }^{\circ} \mathrm{C}$ and after 8 DOR stem cold-hardiness of plants, from all three dehardening treatments, had reached the same level as untreated plants at the beginning of the experiment. 
Table 2. The probabilities of buds being alive, injured, or dead after exposure to $4^{\circ} \mathrm{C}$ or freezing to $-5,-10,-13$, or $-16{ }^{\circ} \mathrm{C}$ as predicted by the proportional odds model. ${ }^{\mathrm{z}}$

\begin{tabular}{|c|c|c|c|c|c|c|}
\hline \multirow{2}{*}{ Treatment } & & \multicolumn{5}{|c|}{ Test temp $\left({ }^{\circ} \mathrm{C}\right)$} \\
\hline & & 4 & -5 & -10 & -13 & -16 \\
\hline \multirow[t]{3}{*}{$\overline{0 \mathrm{DOD}}$} & Alive & 0.98 & 0.93 & 0.61 & 0.47 & 0.44 \\
\hline & Injured & 0.02 & 0.06 & 0.34 & 0.44 & 0.46 \\
\hline & Dead & 0.00 & 0.01 & 0.05 & 0.09 & 0.10 \\
\hline \multirow{3}{*}{$4 \mathrm{DOD}$} & Alive & 0.96 & 0.84 & 0.38 & 0.26 & 0.24 \\
\hline & Injured & 0.04 & 0.14 & 0.50 & 0.54 & 0.54 \\
\hline & Dead & 0.00 & 0.02 & 0.12 & 0.20 & 0.22 \\
\hline \multirow[t]{3}{*}{$8 \mathrm{DOD}$} & Alive & 0.87 & 0.60 & 0.16 & 0.09 & 0.08 \\
\hline & Injured & 0.12 & 0.34 & 0.52 & 0.45 & 0.43 \\
\hline & Dead & 0.01 & 0.06 & 0.32 & 0.46 & 0.49 \\
\hline \multirow[t]{3}{*}{12 DOD } & Alive & 0.65 & 0.29 & 0.05 & 0.03 & 0.02 \\
\hline & Injured & 0.30 & 0.53 & 0.32 & 0.22 & 0.20 \\
\hline & Dead & 0.05 & 0.18 & 0.63 & 0.75 & 0.78 \\
\hline \multirow[t]{3}{*}{4 DOR } & Alive & 0.77 & 0.42 & 0.08 & 0.05 & 0.04 \\
\hline & Injured & 0.20 & 0.47 & 0.43 & 0.31 & 0.30 \\
\hline & Dead & 0.03 & 0.11 & 0.57 & 0.64 & 0.66 \\
\hline \multicolumn{7}{|c|}{$\begin{array}{l}\text { "Buds were evaluated after } 0,4,8 \text {, or } 12 \mathrm{~d} \text { of } \\
\text { dehardening (DOD) at } 15 / 10^{\circ} \mathrm{C} \text { day/night followed } \\
\text { by } 12 \mathrm{~d} \text { of rehardening (DOR). Most buds were } \\
\text { injured or killed after } 6 \mathrm{DOR} \text { as a result of } \\
\text { a significant drop in air temperatures. Therefore, } \\
\text { bud freezing tolerance could not be determined at } \\
8 \text { and } 12 \mathrm{DOR} \text {, and only data from } 4 \text { DOR were } \\
\text { included in the proportional odds model. }\end{array}$} \\
\hline
\end{tabular}

Table 3. The probabilities of buds being alive, injured, or dead after exposure to $4^{\circ} \mathrm{C}$ or freezing to $-5,-10,-13$, or $-16{ }^{\circ} \mathrm{C}$ as predicted by the proportional odds model. ${ }^{\mathrm{z}}$

\begin{tabular}{|c|c|c|c|c|c|c|}
\hline \multirow{2}{*}{\multicolumn{2}{|c|}{ Treatment }} & \multicolumn{5}{|c|}{ Test temp $\left({ }^{\circ} \mathrm{C}\right)$} \\
\hline & & 4 & -5 & -10 & -13 & -16 \\
\hline \multirow[t]{3}{*}{0 DOD } & Alive & 0.98 & 0.93 & 0.61 & 0.47 & 0.44 \\
\hline & Injured & 0.02 & 0.06 & 0.34 & 0.44 & 0.46 \\
\hline & Dead & 0.00 & 0.01 & 0.05 & 0.09 & 0.10 \\
\hline \multirow[t]{3}{*}{4 DOD } & Alive & 0.96 & 0.51 & 0.11 & 0.07 & 0.06 \\
\hline & Injured & 0.04 & 0.41 & 0.48 & 0.37 & 0.35 \\
\hline & Dead & 0.00 & 0.08 & 0.41 & 0.56 & 0.59 \\
\hline \multirow[t]{3}{*}{8 DOD } & Alive & 0.87 & 0.23 & 0.04 & 0.02 & 0.02 \\
\hline & Injured & 0.12 & 0.54 & 0.25 & 0.17 & 0.15 \\
\hline & Dead & 0.01 & 0.23 & 0.71 & 0.81 & 0.83 \\
\hline \multirow[t]{3}{*}{12 DOD } & Alive & 0.65 & 0.08 & 0.01 & 0.01 & 0.01 \\
\hline & Injured & 0.30 & 0.41 & 0.10 & 0.05 & 0.04 \\
\hline & Dead & 0.05 & 0.51 & 0.89 & 0.94 & 0.95 \\
\hline \multirow[t]{3}{*}{4 DOR } & Aliv & 0.77 & 0.13 & 0.02 & 0.01 & 0.01 \\
\hline & Injured & 0.30 & 0.49 & 0.15 & 0.09 & 0.08 \\
\hline & Dead & 0.03 & 0.38 & 0.83 & 0.90 & 0.91 \\
\hline \multicolumn{7}{|c|}{$\begin{array}{l}{ }^{3} \text { Buds were evaluated after } 0,4,8 \text {, or } 12 \mathrm{~d} \text { of } \\
\text { dehardening (DOD) at } 20 / 15^{\circ} \mathrm{C} \text { day/night followed } \\
\text { by } 12 \mathrm{~d} \text { of rehardening (DOR). Most buds were } \\
\text { injured or killed after } 6 \text { DOR as a result of } \\
\text { a significant drop in air temperatures. Therefore, } \\
\text { bud freezing tolerance could not be determined at } 8 \\
\text { and } 12 \text { DOR, and only data from } 4 \text { DOR were } \\
\text { included in the proportional odds model. }\end{array}$} \\
\hline
\end{tabular}

According to the proportional odds model, bud freezing tolerance, assessed as buds being alive, injured, or dead, was significantly affected by both dehardening treatment $(P \leq$ 0.001 ), treatment duration (DOD and DOR, $P \leq 0.001)$, and freeze test temperature $(P \leq$

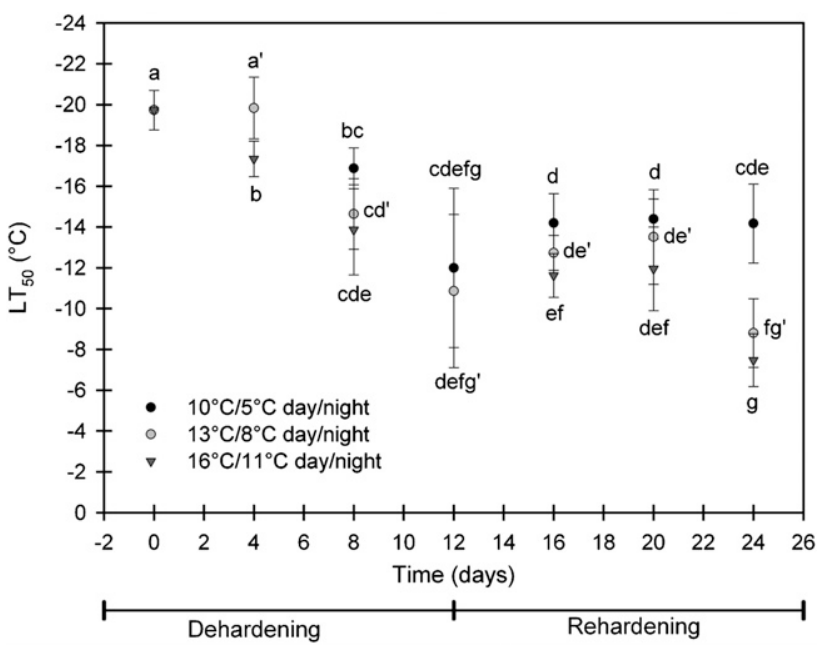

Fig. 4. Cold-hardiness estimated as temperatures representing 50\% relative electrolyte leakage $\left(\mathrm{LT}_{50}\right)$ of stems of Hydrangea macrophylla subjected to $12 \mathrm{~d}$ of dehardening followed by $12 \mathrm{~d}$ of rehardening in March. During dehardening, plants were subjected to the indicated different day and night temperatures. $\mathrm{LT}_{50}$ values [mean $\left.\pm \mathrm{SE}\left({ }^{\circ} \mathrm{C}\right)\right]$ are shown for five plants tested at seven temperatures. Different letters indicate significant differences between $\mathrm{LT}_{50}$ values $(P<0.05)$. After four and $12 \mathrm{~d}$ of dehardening, $\mathrm{LT}_{50}$ values of plants dehardened at $10 / 5{ }^{\circ} \mathrm{C}$ and $16 / 1{ }^{\circ} \mathrm{C}$ day/night could not be accurately estimated because the relative electrolyte leakage data were variable between replicates at specific freezing temperatures. Differences in $\mathrm{LT}_{50}$ values of plants dehardened at $13 / 8{ }^{\circ} \mathrm{C}$ day/night are indicated by marked letters for clarity.

0.001). The likelihood of survival (with or without injuries) was greater for buds dehardened at $10 / 5^{\circ} \mathrm{C}$ than for buds dehardened at $15 / 10^{\circ} \mathrm{C}$ or $20 / 15{ }^{\circ} \mathrm{C}$ (odds ratios of 0.27 and 0.10 , respectively). Similarly, the likelihood of buds surviving control temperatures $\left(4{ }^{\circ} \mathrm{C}\right)$ was higher than the likelihood of buds surviving freezing to $-5^{\circ} \mathrm{C}$ (odds ratio of 0.24 ) and particularly to $-10,-13$, or $-16^{\circ} \mathrm{C}$ (odds ratios of $0.030,0.017$, and 0.015 , respectively). The ability of buds to withstand freezing temperatures decreased with increasing dehardening duration but increased again at 4 DOR. The predicted probabilities of buds being alive, injured, or dead after freezing to different temperatures depending on the dehardening regime are given in Tables 1 to 3. At 0 DOD, $\approx 45 \%$ of the buds were predicted to survive, without injuries, freezing to -13 and $-16{ }^{\circ} \mathrm{C}$. Another $45 \%$ were predicted to become injured, whereas only a small percentage was predicted to die. Four d at $10 / 5{ }^{\circ} \mathrm{C}$ did not decrease bud hardiness, whereas after 8 DOD, the predicted probabilities of buds being injured or dead increased when frozen to $-10{ }^{\circ} \mathrm{C}$ and lower temperatures (Table 1 ). This trend was enhanced at 12 DOD. In plants dehardening at $15 / 10^{\circ} \mathrm{C}$, the predicted probabilities of injured and dead buds increased at 4 DOD compared with 0 DOD and hardiness decreased further at 8 and 12 DOD (Table 2). Dehardening of buds occurred at an increased rate at $20 / 15^{\circ} \mathrm{C}$ (Table 3). At the end of the dehardening treatment, on average $4.5 \%$ and $9 \%$ of the buds of plants dehardened at $15 / 10{ }^{\circ} \mathrm{C}$ and $20 / 15{ }^{\circ} \mathrm{C}$, respectively, had initiated budbreak. None of the buds of plants dehardened at $10 / 5^{\circ}$ had started to break (data not shown).

During rehardening, the air temperature in the greenhouse decreased to almost $-10{ }^{\circ} \mathrm{C}$ after 6 DOR (Fig. 2A), which injured or killed most buds of the rehardening plants. Therefore, bud freezing tolerance could not be determined at 8 and 12 DOR, and only data from 4 DOR were included in the proportional odds model and shown in Tables 1 to 3. In plants dehardened at $10 / 5{ }^{\circ} \mathrm{C}$ or $15 / 10$ ${ }^{\circ} \mathrm{C}, 4$ DOR increased the predicted probabilities of buds surviving the different freezing temperatures as compared with 12 DOD. This indicated that buds were able to reharden. In plants dehardened at $20 / 15^{\circ} \mathrm{C}$, only slight increases in the predicted probabilities of surviving or injured buds were observed after 4 DOR as compared with 12 DOD and only in buds frozen to $-5^{\circ} \mathrm{C}$.

At the beginning of March, stem coldhardiness of plants that had remained in the field was greater than in January (compare Figs. 3 and 4, 0 DOD). However, dehardening proceeded faster in March than in January and after 4 DOD, a significant decrease in hardiness of plants subjected to $16 / 11^{\circ} \mathrm{C}$ day/ night was determined (Fig. 4). After 8 DOD, stem hardiness had decreased significantly in all three treatments, and at 8 and 12 DOD, there were no statistically significant differences in stem hardiness between treatments. In March, none of the plants rehardened under natural conditions. Plants dehardened at $10 / 50{ }^{\circ} \mathrm{C}$ remained stable when they were moved outdoors for rehardening, whereas at 12 DOR, plants dehardened at $13 / 8{ }^{\circ} \mathrm{C}$ or $16 /$ $11^{\circ} \mathrm{C}$ had lost further stem cold-hardiness.

\section{Discussion}

Midwinter stem hardiness of H. macrophylla, determined at the beginning of January, was similar to that previously reported (Adkins et al., 2003; Pagter et al., 2011). It 
was surprising to determine that stem hardiness at the beginning of March was $2.5^{\circ} \mathrm{C}$ higher than in January. This increase in freeze tolerance likely reflects the particularly cold climate in Jan. and Feb. 2010 (Fig. 1).

In January, a significant drop in stem coldhardiness was observed after 8 DOD in plants dehardened at $15 / 10^{\circ} \mathrm{C}$ or $20 / 15^{\circ} \mathrm{C}$ (Fig. 3). This is somewhat different from previous results, in which a significant loss of coldhardiness after 3 DOD in plants dehardened at $22 / 17^{\circ} \mathrm{C}$ day/night was observed (Pagter et al., 2011). The greater dehardening resistance of $H$. macrophylla in the present study, carried out in early January, compared with previously reported studies, carried out in February (Pagter et al., 2011), may indicate that $H$. macrophylla loses resistance to dehardening as winter progresses. In the present study, data from the March experiment (Fig. 4) supported the suggestion that dehardening resistance of $H$. macrophylla is influenced by the progression of winter, because stem dehardening proceeded faster in March than in January despite lower dehardening temperatures. In buds of azaleas (Rhododendron L.) (Kalberer et al., 2007b) and some raspberry cultivars (Rubus idaeus L.) (Palonen and Lindén, 1999), dehardening resistance also decreased as the season progressed and according to Sakai and Larcher (1987), plants are in general more rapidly dehardened in late winter than at the onset of winter. Alternatively, the difference in dehardening resistance may be the result of lower dehardening temperatures in the present study than those reported previously (Pagter et al., 2011).

Dehardening of stems in January was both delayed and slower in plants dehardened at $10 / 5^{\circ} \mathrm{C}$ compared with plants dehardened at higher temperatures (Fig. 3). The rate of dehardening has previously been reported to increase with temperature in other plant species (Eagles and Williams, 1992; Svenning et al., 1997). In contrast, there were no significant differences in cold-hardiness of plants dehardened at $15 / 10^{\circ} \mathrm{C}$ or $20 / 15^{\circ} \mathrm{C}$ at 4,8 , and 12 DOD. This may suggest that in $H$. macrophylla, the rate of dehardening of stems increased with temperature until a certain threshold and at temperatures higher than the threshold, dehardening was not accelerated further. In the white clover cultivar AberHerald (Trifolium repens L.), dehardening at 12 and $18{ }^{\circ} \mathrm{C}$ was similar (Svenning et al., 1997), and in a model assessing the risk of frost damages in Norway spruce (Picea abies L.), the rate of dehardening also did not change when the daily mean temperatures were above $15{ }^{\circ} \mathrm{C}$ (Jönsson et al., 2004). In March, dehardening of $H$. macrophylla stems generally proceeded faster at higher than at lower temperatures, but at 8 and $12 \mathrm{DOD}$, the effect of dehardening temperatures on the $\mathrm{LT}_{50}$ values was not statistically significant (Fig. 4). The dehardening temperatures chosen in March may not have been sufficiently different to resolve significant differences, if any, between the treatments at 8 and 12 DOD or differences were masked by the sES.
Because REL is expressed in percentage, the variation between individual samples decreases when damage is close to either zero or $100 \%$. The large ses of the $\mathrm{LT}_{50}$ estimates at 8 and 12 DOD may therefore indicate that within a treatment, some plants were more advanced in the dehardening process than others.

Although plants in the two warmest dehardening regimes had lost approximately two-thirds of their acclimated cold-hardiness (based on an $\mathrm{LT}_{50}$ value of non-acclimated stems at $-5{ }^{\circ} \mathrm{C}$; Pagter et al., 2008), stems of plants from all three treatments were able to reharden in January. Four d of low-temperature exposure was sufficient to induce a significant increase in hardiness and after 8 DOR dehardening was completely reversed, indicating that the capacity for rehardening was intact. Rapid rehardening has also been observed in different tissues of other plants (Beck et al., 2004; Kalberer et al., 2007a, 2007b; Neuner et al., 1999; Szalay et al., 2010). In contrast, in stems of $H$. paniculata, rehardening at $-15{ }^{\circ} \mathrm{C}$ after 3 or $7 \mathrm{~d}$ of dehardening at $12{ }^{\circ} \mathrm{C}$ did not affect stem hardiness (Suojala and Lindén, 1997). In March, no rehardening was observed in stems of H. macrophylla, although the loss of hardiness after 12 DOD was similar in January and March. Whether this was the result of a lack of rehardening capacity in H. macrophylla, suggesting rehardening was also influenced by the progression of winter, or whether the outdoor temperatures in March were too high to effectively induce rehardening is unknown. However, because the average temperature during the first 4 DOR was similar to or lower than temperatures that effectively induce rehardening in other species (Kalberer et al., 2007b) and that are normally conducive to increased cold hardening (Renaut et al., 2006), it seems likely that a lack of increased hardiness within 4 DOR was the result of a slower and/or reduced capacity for rehardening in March compared with January. Conversely, the high air temperatures during the last $8 \mathrm{~d}$ of the rehardening period in March presumably explain why stem hardiness remained unchanged at $8 \mathrm{DOR}$, and even decreased at $12 \mathrm{DOR}$, in plants dehardened at $13 / 8{ }^{\circ} \mathrm{C}$ or $16 / 11^{\circ} \mathrm{C}$.

Although the cumulative probabilities of bud survival and injury are not directly comparable to the $\mathrm{LT}_{50}$ values obtained for stems, estimated survival percentages at 0 DOD of $47 \%$ and $44 \%$ at -13 and $-16{ }^{\circ} \mathrm{C}$, respectively, suggested that buds of $H$. macrophylla at midwinter were slightly less cold-hardy than stems. However, because "injured" in most cases meant browning of the flower primordia, this category is similar to "dead" with respect to capacity to flower, and in practice buds may therefore appear even less freezing-tolerant. Increasing temperatures enhanced dehardening of buds and unlike in stems, this was also apparent when comparing the effect of the two warmest dehardening treatments $\left(20 / 15{ }^{\circ} \mathrm{C}\right.$ and $15 / 10^{\circ} \mathrm{C}$ ). Compared with stems, dehardening of buds appeared to be faster with predicted probabilities of surviving buds at the lowest temperatures decreasing after 8 DOD at $10 / 5^{\circ} \mathrm{C}$ and $4 \mathrm{DOD}$ at $15 / 10^{\circ} \mathrm{C}$ or $20 / 15^{\circ} \mathrm{C}$. Less resistance to dehardening and faster dehardening in buds, than in stems, was also indicated by the fact that at 12 DOD, buds at $20 / 15{ }^{\circ} \mathrm{C}$ seemed to have lost all of their acclimated hardiness. Thus, it is tempting to speculate that in H. macrophylla in addition to a slightly lower absolute hardiness, there is a greater susceptibility of the buds than the stems to frost injury because of less dehardening resistance and faster dehardening. This is opposite to $H$. paniculata, in which buds are considerably more cold-tolerant and more resistant to deacclimation than stems (Suojala and Lindén, 1997). As a result of the limited data set, a cautious interpretation of the rehardening capacity of buds is required. However, buds of plants dehardened at 15/ $10{ }^{\circ} \mathrm{C}$ and particularly $10 / 5{ }^{\circ} \mathrm{C}$ appeared to have retained the ability to reharden. Contrary, in plants dehardened at $20 / 15^{\circ} \mathrm{C}$, only minor increases in the predicted probabilities of buds surviving or being injured at $-5^{\circ} \mathrm{C}$ were observed at 4 DOR, suggesting that the buds were unable to or had very limited capacity for rehardening. It has been suggested that dehardening becomes irreversible and tissues lose their capacity to reharden after development and elongation growth has been initiated in the spring (Jouve et al., 2007; Rapacz, 2002). In the present study, a lack of rehardening was also associated with renewed growth, because $9 \%$ of the buds of plants dehardened at the highest temperatures had initiated budbreak at 12 DOD.

In conclusion, the present study confirmed that buds of $H$. macrophylla were slightly less cold-hardy than stems. In both stems and buds, dehardening resistance and the rate of dehardening were influenced by temperature, but buds seemed less resistant to dehardening and dehardened faster than stems. Rehardening of stems was effective midwinter even after substantial dehardening, indicating that rehardening may be an important component of winter survival in H. macrophylla. In late winter/early spring, the effect of an unstable temperature regime on the frequency and severity of frost injuries in stems may be far greater as a result of a lower dehardening resistance, increased rate of dehardening, and likely reduced and/or slower capacity to reharden. The expected increased frequency of atypical temperature extremes during the winter season necessitates that midwinter-hardiness, dehardening resistance, and rehardening capacity are important considerations when introducing new $H$. macrophylla cultivars.

\section{Literature Cited}

Adkins, J.A., M.A. Dirr, and O.M. Lindstrom. 2003. Cold hardiness estimates of ten Hydrangea taxa. Acta Hort. 618:163-168.

Beck, E.H., R. Heim, and J. Hansen. 2004. Plant resistance to cold stress: Mechanisms and environmental signals triggering frost hardening and dehardening. J. Biosci. 29:449-459.

Burr, K.E., C.D.B. Hawkins, S.J.L. Hirondelle, W.D. Binder, M.F. George, and T. Repo. 2001. 
Methods for measuring cold hardiness of conifers, p. 369-401. In: Bigras, F.J. and S.J. Colombo (eds.). Conifer cold hardiness. Kluwer Academic Publishers, Dordrecht, The Netherlands.

Cox, S.E. and C. Stushnoff. 2001. Temperaturerelated shifts in soluble carbohydrate content during dormancy and cold acclimation in Populus tremuloides. Can. J. For. Res. 31:730-737.

Eagles, C.F. and J. Williams. 1992. Hardening and dehardening of Lolium perenne in response to fluctuating temperatures. Ann. Bot. (Lond.) 70:333-338

Fitter, A.H. and R.S.R. Fitter. 2002. Rapid changes in flowering time in British plants. Science 296:1689-1691.

Fosket, D.E. 1994. Plant growth and development. A molecular approach. Academic Press, San Diego, CA., p. 271-340.

Gu, L., P.J. Hanson, W. Mac Post, D.P. Kaiser, B. Yang, E. Nemani, S.G. Pallardy, and T. Meyers. 2008. The 2007 eastern US spring freeze: Increased cold damage in a warming world? Bioscience 58:253-262.

Jönsson, A.M., M.-L. Linderson, I. Stjernquist, P. Schlyter, and L. Bärring. 2004. Climate change and the effect of temperature backlashes in causing frost damage in Picea abies. Global Planet. Change 44:195-207.

Jouve, L., D. Jacques, G.C. Douglas, L. Hoffmann, and J.F. Hausmann. 2007. Biochemical characterization of early and late bud flushing in common ash (Fraxinus excelsior L.). Plant Sci. 172:962-969.

Kalberer, S.R., N. Leyva-Estrada, S.L. Krebs, and R. Arora. 2007a. Frost dehardening and rehardening of floral buds of deciduous azaleas are influenced by genotypic biogeography. Environ. Exp. Bot. 59:264-274.

Kalberer, S.R., R. Arora, N. Leyva-Estrada, and S.L. Krebs. 2007b. Cold hardiness of floral buds of deciduous azaleas: Dehardening, rehardening, and endodormancy in late winter. J. Amer. Soc. Hort. Sci. 132:73-79.

Kalberer, S.R., M. Wisniewski, and R. Arora. 2006. Deacclimation and reacclimation of cold-hardy plants: Current understanding and emerging concepts. Plant Sci. 171:3-16.

Karlsen, S.R., I. Solheim, P.S.A. Beck, K.A. Høgda, F.E. Wielgolaski, and H. Tømmervik. 2007. Variability of the start of the growing season in Fennoscandia, 1982-2002. Intl. J. Biometeorol. 51:513-524.

McClintock, E. 1957. A monograph of the genus Hydrangea. Proc. Calif. Acad. Sci. 29:147256.

McCullagh, P. 1980. Regression models for ordinal data. J. Roy. Stat. Soc. B Met. 42:109-142.

Neuner, G., D. Ambach, and O. Buchner. 1999. Readiness to frost harden during the dehardening period measured in situ in leaves of Rhododendron ferrugineum L. at the alpine timberline. Flora 194:289-296.

Pagter, M., J.-F. Hausman, and R. Arora. 2011. Deacclimation kinetics and carbohydrate changes in stem tissues of Hydrangea in response to an experimental warm spell. Plant Sci. 180:140-148.

Pagter, M., C.R. Jensen, K.K. Petersen, F. Liu, and R. Arora. 2008. Changes in carbohydrates, ABA and bark proteins during seasonal cold acclimation and deacclimation in Hydrangea species differing in cold hardiness. Physiol. Plant. 134:473-485.
Palonen, L. and L. Lindén. 1999. Dormancy, cold hardiness, dehardening, and rehardening in selected red raspberry cultivars. J. Amer. Soc. Hort. Sci. 124:341-346.

Rapacz, M. 2002. Cold-deacclimation of oilseed rape (Brassica napus var. oleifera) in response to fluctuating temperatures and photoperiod. Ann. Bot. (Lond.) 89:543-549.

Renaut, J., J.F. Hausman, and M.E. Wisniewski. 2006. Proteomics and low-temperature studies: Bridging the gap between gene expression and metabolism. Physiol. Plant. 126:97-109.

Sakai, A. and W. Larcher. 1987. Frost survival of plants. Responses and adaptation to freezing stress. Springer-Verlag, Heidelberg, Germany.

Sauter, J.J., M. Wisniewski, and W. Witt. 1996. Interrelationships between ultrastructure, sugar levels and frost hardiness of ray parenchyma cells during frost acclimation and deacclimation in poplar (Populus $\times$ canadensis Moench $<$ robusta $>$ ) wood. J. Plant Physiol. 149:451461.

Suojala, T. and L. Lindén. 1997. Frost hardiness of Philadelphus and Hydrangea clones during ecodormancy. Acta Agr. Scand. B-S. 47:5863.

Svenning, M.M., K. Røsnes, and O. Junttila. 1997. Frost tolerance and biochemical changes during hardening and dehardening in contrasting white clover populations. Physiol. Plant. 101:31-37.

Szalay, L., B. Timon, S. Németh, J. Papp, and M. Tóth. 2010. Hardening and dehardening of peach flower buds. HortScience 45:761-765.

Väinolä, A. and T. Repo. 1999. Cold hardiness of diploid and corresponding autotetraploid rhododendrons. J. Hort. Sci. Biotechnol. 74:541-546. 